\title{
Eurocentrismo y orientalismo en los libros de texto de historia antigua de las escuelas secundarias de la Argentina (1890-1950)
}

4 Sergio Daniel Cubilla

Universidad Nacional de Luján / Instituto Superior del Profesorado “Dr. Joaquín V. González", Argentina

Fecha de recepción: 10 de abril de 2020. Fecha de aceptación: 28 de abril de 2020 .

\section{Resumen}

El presente trabajo ${ }^{1}$ de investigación procura rastrear y analizar las concepciones o representaciones del discurso eurocéntrico y orientalista sobre las sociedades de la antigüedad que se presentan en los libros de texto de historia antigua. Estos fueron utilizados en las escuelas secundarias de la Argentina en el período que va de 1890 a 1950. A partir del análisis de estas fuentes, nos proponemos por consiguiente indagar en la apropiación de los valores culturales occidentales/ europeos, que tuvo lugar en la Argentina durante los siglos XIX y XX y que, como demuestra el análisis realizado, fue reproducida en dichos manuales escolares.

Palabras clave: eurocentrismo, orientalismo, libros de texto, discursos, representaciones

Eurocentrism and Orientalism in Ancient History Textbooks in Secondary Schools of Argentina (1890-1950)

\footnotetext{
Abstract

The present investigation aims to trace and analyze the Eurocentric and Orientalist conceptions or representations about ancient societies appearing

1 El presente artículo constituye una síntesis de la tesis realizada en el marco de la Maestría en Ciencias Sociales con mención en Historia Social de la Universidad Nacional de Luján, intitulada Eurocentrismo y orientalismo en los libros de texto de historia antigua de las escuelas nacionales, normales y comerciales de la Argentina (1890-1950). La nación argentina en el marco de la civilización occidental y defendida en diciembre de 2018. La misma se encuentra disponible en: http://ri.unlu.edu.ar/xmlui/handle/rediunlu/357.
} 
in Ancient History textbooks used in secondary schools in Argentina in the period 1890-1950. From the analysis of these sources, an inquiry is performed regarding the appropriation of Western/European cultural values, which took place in Argentina during the 19th and 20th centuries and seemed to have utilized the discourse in these textbooks as propagation means.

Keywords: Eurocentrism, Orientalism, Textbooks, discourses, representations

\section{Introducción}

En los estudios sobre la construcción de representaciones sobre los "otros" y la apropiación de los valores culturales occidentales entre fines del siglo XIX y comienzos del siglo XX en la Argentina, destaca el análisis de los textos escolares. Así lo demuestran los trabajos de Fernando Devoto (1993), Luciano De Privitellio (1999), Luis Alberto Romero (2004, 2009, 2010), Teresa Artieda (2001, 2010), Mirta Teobaldo (2007, 2008), entre otros. El creciente interés de los investigadores por este tipo de fuentes proviene, como afirma Palmira Dobaño, de la renovación historiográfica producida en la década de 1970, del giro lingüístico y de la creciente importancia de la historia de las ideas (Dobaño, 2001). En efecto, estos textos brindan, por su estructura formal, por ser el saber enseñado y transmitido y por ser un recurso didáctico primordial, un observatorio de primera mano para analizar las concepciones y representaciones vigentes en un determinado momento histórico. ${ }^{2}$ Sin embargo, en los estudios disponibles, la atención ha estado concentrada preferentemente en la historia argentina, excluyendo otras áreas de la disciplina, como por ejemplo la antigüedad. Esta práctica ausencia aparece entonces como una oportunidad para abordar el estudio de las maneras en cómo se difundieron y reprodujeron algunos de los valores culturales occidentales a través de la enseñanza de la historia antigua. La elección de este marco temporal viene dada por ser éste el período en el cual se inicia y se profundiza la producción de este tipo de obras académicas, es decir, manuales de historia antigua publicados en el país y escritos por autores argentinos. No obstante, esta investigación se detendrá en 1950 y no proseguirá hacía décadas siguientes ya que eso implicaría extendernos en demasía en un análisis cuantitativo que escaparía a los límites del presente trabajo además de contar ya con algunos pocos artículos que han indagado en obras similares de la segunda mitad del siglo XX.

En este sentido, hemos encontrado dos trabajos que pueden resultar útiles a los fines de nuestra tarea investigativa. El primer trabajo es el de Andrea

2 En las últimas décadas, la investigación referida a libros de texto ha tenido un importante desarrollo y expansión de la mano del proyecto MANES, que es una propuesta interuniversitaria de investigación sobre los manuales escolares españoles que comenzó en 1992 y luego se amplió a otras universidades latinoamericanas que adhirieron a la iniciativa. También vale destacar la existencia y el rol del Georg-Eckert-Institut für Internationale Schulbuchforschung de Alemania, que realiza desde hace décadas un interesante trabajo interdisciplinar con investigadores latinoamericanos indagando en la creación de imaginarios e identidades a través de los libros de texto. Véase: Ossenbach (2000); Kaufmann (2002); Riekenberg (1991). 
Zingarelli, "Algunas consideraciones sobre la propuesta editorial para la enseñanza de la Historia Antigua" (1996). En el mismo se realiza un análisis crítico del enfoque historiográfico, metodológico y didáctico con que se presentan los contenidos de historia antigua en una serie de libros de texto de las décadas de 1980 y 1990. Asimismo, la autora lleva su análisis un poco más atrás en el tiempo a los manuales de historia antigua y medieval de José Cosmelli Ibáñez y de Alfredo Drago, editados en los años 1965 y 1966 respectivamente, donde predominaba un enfoque tradicional de corte positivista. Una de las características que este último enfoque ha dejado en los libros de texto, analizados por la autora, y también en la tradición escolar, es el fuerte ordenamiento cronológico y la acumulación de datos factuales en sus páginas que, según Zingarelli, fortalecen un aprendizaje de tipo memorístico. Por otra parte, lo que destaca es la recurrencia de explicaciones causales, sobre todo a partir del accionar de "grandes personajes" que influyen de manera determinante sobre el devenir de los procesos históricos (Zingarelli, 1996: 81-82).

Por otra parte, un artículo de Ramón López Facal también merece ser destacado. Este trabajo versa sobre la presencia de los enfoques nacionalistas tradicionales en los libros de texto de España, los cuales a partir de los años '70 conviven con el europeísmo, una cierta noción de pertenencia a Europa cada vez más fuerte. Según el autor, este carácter eurocéntrico de la historia enseñada se expresa claramente en los libros escolares donde la historia de Europa aparece como una excepcionalidad y casi completamente desligada de los aportes de otras culturas, por ejemplo, de Asia o África. Es importante rescatar las palabras del autor:
Las únicas menciones a culturas no europeas se limitan a las "primeras civilizaciones" de Mesopotamia y Egipto, y "desaparecen" de la historia enseñada, al menos hasta finales del siglo XX. Por otra parte, esta presencia parece venir justificada por ser la cuna o precedente de la civilización (por supuesto europea) sin que se ofrezca la menor información sobre lo ocurrido allí posteriormente ni, mucho menos, sobre las sociedades que se desarrollaron en la India o China. (López Facal, 2010: 23).

Tal como lo plantea el autor, el pasado se ha simplificado y reducido a la historia estrictamente europea en todos los períodos históricos, de tal manera que la antigüedad se reduce al mundo grecolatino, cuna originaria de la cultura europea por venir. El análisis del discurso eurocéntrico y etnocentrista de los libros de texto de historia españoles que realiza López Facal resulta de utilidad, ya que constituye un ejemplo de análisis discursivo que la presente investigación ha recuperado.

Por otra parte, cabe destacar el análisis que realiza Sophie Bessis en su libro Western Supremacy. The Triumph of an Idea, acerca de los libros de texto publicados con posterioridad al proceso de descolonización en países como España, Francia y Estados Unidos, en los cuales, argumenta la autora, se sigue sosteniendo un discurso legitimador del imperialismo y colonialismo decimonónicos (Bessis, 2003: 44-46). Si bien no hemos podido encontrar otros trabajos directamente vinculados con los manuales de historia antigua, hemos identificado asimismo investigaciones sobre libros de texto escolares de nivel primario y 
secundario que, a pesar de abordar la historia argentina, nos pueden servir también como antecedentes teóricos y metodológicos a partir de los cuales realizar nuestra labor. En efecto, tanto la relación con los estados nacionales fronterizos, como también con las poblaciones indígenas, han sido categorizadas a partir de conceptos tales como "barbarie", "sociedades a-históricas" y "desierto", elementos tradicionales del discurso eurocéntrico y orientalista (Artieda, 2001, 2010; Gvirtz, 2001; Romero, 2004, 2009, 2010; Teobaldo, 2007, 2008).

\section{Eurocentrismo, orientalismo y ciencias sociales}

Uno de los teóricos más importantes que se han abocado al estudio del eurocentrismo es Samir Amin quien, en su obra Eurocentrismo. Crítica de una ideología, ha analizado no sólo los orígenes y la construcción de este concepto, sino también sus estrategias de reproducción. Para Amin, el eurocentrismo es un fenómeno que se caracteriza por ser una dimensión de la cultura y de la ideología del mundo capitalista, cuyos orígenes pueden remontarse hasta el Renacimiento europeo y cuya difusión global se hace patente en el siglo XIX. Se sitúan los orígenes del concepto en el Renacimiento porque es en el siglo XVI cuando se producen las dos transformaciones decisivas del mundo moderno, por un lado, la consolidación de la sociedad capitalista en Europa y, por otra parte, la conquista de gran parte del mundo llevada adelante por esta. En consecuencia, estas transformaciones dieron lugar a la conformación de un paradigma global con tendencias universalistas (Amin, 1989: 11-21).

La ideología eurocéntrica procuró rastrear sus orígenes en la mismísima antigüedad, a través del denominado "mito del ancestro griego". Este consiste en la apropiación del pasado y el legado cultural griego tomándolo como el nacimiento de la europeidad y desvinculando a Grecia del universo cultural al que pertenecía, a saber, el ahora llamado "Oriente". En este sentido, cabe destacar aquí lo planteado por Martin Bernal en su renombrada obra Black Athena (Atenea Negra) de 1987, en la cual procuró demostrar los aportes de las culturas egipcia y semita en la formación de la civilización griega. Según Bernal, los intelectuales europeos del siglo XVII, pero sobre todo a partir del siglo XVIII, se propusieron y se dedicaron con tesón a la sustitución de lo que el autor denomina el "Modelo Antiguo", que aceptaba las influencias de la cultura egipcia y fenicia en la formación de la Grecia antigua, por un denominado "Modelo Ario" que negaba terminantemente la influencia de dichas culturas en los orígenes de la cultura griega. Este modelo se alimentaba de concepciones racistas en un contexto signado por la hegemonía de las nociones de ciencia y progreso que caracterizaron a los siglos XVIII y XIX. De esta manera, se instaló la concepción de que la civilización griega pertenecía a la familia aria o indoeuropea y por ello sin ningún tipo de aportes africanos o asiáticos (Bernal, 1993 [1989]: 57). A partir de entonces el destino del Occidente europeo se encontraba marcado y garantizado por un desarrollo lineal y evolutivo compuesto por la Grecia antigua, Roma, la Europa cristiana feudal y luego capitalista. En este sentido, Amin destaca también la apropiación del cristianismo considerado por la ideología eurocéntrica como un fenómeno religioso plenamente europeo y por ello superior a los demás. 
El mito del ancestro griego representa tanto un punto de partida como un punto de ruptura. Un punto de partida en cuanto a los orígenes del binomio de un Occidente civilizado y un Oriente bárbaro y un punto de ruptura en cuanto que a partir de entonces se produce el nacimiento de la filosofía y de la razón alcanzados por los griegos, entendidos como los primeros europeos, mientras que Oriente jamás habría logrado superar la metafísica. He aquí el nacimiento del otro, el Oriente, el cual está destinado también al fracaso civilizatorio, tal como lo intenta explicar la lingüística del siglo XIX que oponía los pueblos de lenguas indoeuropeas, proclives a la libertad y a la razón, a los pueblos de lenguas semitas, proclives a la servidumbre y al despotismo (Amin, 1989: 88-91). La idea de raza fue elaborada y utilizada para categorizar a las poblaciones no europeas de todo el planeta, las cuales serían consideradas inferiores y productoras de culturas también caracterizadas por su inferioridad y atraso en términos civilizatorios. El etnocentrismo del eurocentrismo se articula aquí con la idea de raza y la idea de evolución. Esta última consideraba que todas las culturas no europeas formaban parte del pasado por lo cual Europa era la vanguardia de la historia universal “... ya que [los europeos] eran naturalmente (racialmente) superiores a todos los demás, puesto que habían conquistado a todos y les habían impuesto su dominio" (Quijano, 2000: 221).

Por otra parte, Immanuel Wallerstein ha señalado el carácter eurocéntrico de las ciencias sociales, ya que éstas son producto del sistema mundo moderno y de dicho paradigma. En este sentido, repasa los diferentes cuestionamientos hacia este puntualizando en los aspectos considerados a continuación: en su historiografía; en su universalismo y provincialismo; en sus presupuestos sobre la civilización; en su orientalismo y en la imposición de la teoría del progreso. Al referirse al segundo de ellos, el autor plantea que las ciencias sociales han sido universalistas porque sostienen la concepción de que lo experimentado por la Europa de entre los siglos XVI y XIX representaba la cúspide del desarrollo social en términos evolutivos y que dicho modelo se podría y debería aplicar a todas las experiencias sociales. Por ello, también fueron acusadas de particularistas y provincianas en cuanto esto implicaba generalizar la experiencia histórica de Europa occidental a todas las experiencias sociales. Esta concepción se inspiraba en la ciencia de Isaac Newton (1643-1727) y René Descartes (1596-1650), la cual influirá de manera decisiva sobre las ciencias sociales (Wallerstein, 2000:97-113).

Edgardo Lander destaca dos aspectos de la constitución de las ciencias sociales que deben tenerse en cuenta. Por un lado, la existencia de un relato universal de carácter evolutivo que sostiene la necesidad del paso de las culturas y sociedades primitivas o tradicionales a una instancia de modernización. El punto de llegada lo constituye la sociedad industrial moderna representada por el modelo europeo y aquellas que no logren avanzar hacia ese destino manifiesto estarán destinadas a desaparecer. Por otro lado, los saberes científicos producidos en las poblaciones modernas serían los únicos válidos y los conceptos forjados por dichas disciplinas serían los necesarios para estudiar, analizar y caracterizar a las sociedades no europeas. Así pues, las sociedades que quedaran fuera de este camino hacia la modernidad, representando lo primitivo, lo arcaico, lo salvaje, solo podrían recibir dos opciones de tratamiento: la imposición de la civilización y sus valores occidentales o su simple aniquilamiento. Justamente, esta es una de las preocupaciones que destaca Lander en las élites latinoamericanas de fines del siglo XIX y principios del siglo XX (Lander, 2000: 26). 
Podemos coincidir entonces con Santiago Castro Gómez cuando sostiene que las ciencias sociales y los saberes producidos por estas se han formado dentro del denominado espacio moderno colonial, de tal forma que "...las ciencias sociales no efectuaron jamás una 'ruptura epistemológica' -en el sentido althusseriano- frente a la ideología, sino que el imaginario colonial impregnó desde sus orígenes a todo su sistema conceptual" (Castro Gómez, 2000: 153). Es decir, entonces, que las ciencias sociales, sus teóricos así como sus saberes y conceptos, resultaron un instrumento eficaz para legitimar el poder de los estados nacionales europeos hacia adentro así como la expansión colonial de los mismos y del sistema capitalista moderno hacia el exterior de Europa.

Una de las dimensiones del paradigma del eurocentrismo es el llamado orientalismo y entre los primeros teóricos que se abocaron a su estudio y a su análisis se encuentran Anouar Abdel Malek (1963) y el siempre citado Edward Said, quien publicara su obra fundamental, Orientalismo, en el año 1978. Según este último, la oposición entre la cultura europea y las culturas del mundo oriental ha sido el producto de un largo proceso de construcción intelectual que dio forma al discurso orientalista. Pero, ¿qué es el orientalismo? Said lo define como un discurso intelectual a partir del cual Europa se relaciona con Oriente y a través del cual ejerce su autoridad y su dominio sobre él. Ahora bien, este discurso europeo se apoya en instituciones, tanto académicas como gubernamentales, que ejercen un control directo sobre el mundo oriental. Por esta razón, el orientalismo es resultado de una relación de poder entre Occidente y Oriente que se ha dado en un determinado contexto histórico: la expansión colonial europea, sobre todo británica y francesa, durante los siglos XVIII y XIX (Said, 2004 [1978]). El contenido del discurso orientalista consiste en representar estereotipos acerca de lo oriental, como la inmovilidad y la inmanencia de las sociedades orientales, el carácter naturalmente despótico, la religiosidad mística, la sexualidad insaciable y el exotismo femenino. Esta división ontológica entre Oriente y Occidente se ha construido y reproducido con el aporte de numerosos intelectuales que Said rastrea hasta la antigüedad clásica, de la mano de Esquilo y sus obras. En relación a éste, lo sitúa como uno de los primeros orientalistas (entre los cuales también incluye a Homero), y destaca su obra Los persas como una de las primeras representaciones de lo oriental. Es en este contexto que la historia de la Grecia antigua adquiere una singular importancia, dado que la misma fue tomada por los eruditos del Romanticismo alemán del siglo XVIII para construir el concepto de lo clásico, tejiendo hábilmente una continuidad entre la antigüedad griega y el presente europeo de los siglos XVIII y XIX (Dussel, 2001: 43).

\section{El contexto ideológico y las normativas curriculares del período 1890-1950}

¿Cuáles son los principales discursos intelectuales de la Argentina del siglo XIX y las primeras décadas del siglo XX? Y, ¿en qué medida se reproducían o se apropiaban ideas, concepciones y estereotipos del paradigma del eurocentrismo y del discurso del orientalismo? Estudios anteriores y relativamente recientes han propuesto la viabilidad de utilizar el corpus teórico propuesto por Edward 
Said en su obra Orientalismo para analizar los discursos que construyen jerarquías y representaciones sobre los "otros" en el marco de la historia cultural latinoamericana (Nagy-Zekmi, 2008; Gasquet, 2008, 2015).

La proyección del discurso del orientalismo es un rasgo de notoria antigüedad en el continente americano, ya que los mismos colonizadores españoles habrían proyectado la sombra de lo oriental al comparar a los indígenas con los moros. La imagen del oriental, entonces, tuvo una rápida asimilación por parte de los conquistadores europeos que utilizaban dicha representación para categorizar aquello desconocido y, por ende, entendido como inferior. De esta manera, la población originaria de América fue representada por los conquistadores europeos como poseedores de cualidades que los situaban en las fronteras de la barbarie, tales como el canibalismo, una sexualidad desenfrenada y anormal, entre otras.

Esta misma estrategia discursiva fue rescatada y utilizada por los criollos americanos en tiempos de la ruptura del pacto colonial y de las guerras de independencia para desvirtuar la autoridad de la corona española y legitimar sus deseos de independencia política. En este sentido, España fue asociada por parte de pensadores ingleses y franceses al mundo oriental y era discriminada por su cercanía a África por lo cual se le atribuyeron las características que se le acreditaban a las sociedades orientales desde antaño, como ser su despotismo, la crueldad, el fanatismo, la debilidad, etc., al punto que sus autoridades eran denominadas "sultanes", "sátrapas", y los españoles en general "sarracenos" (Taboada, 2008).

Esto se vio disparado y profundizado por diferentes acontecimientos y canales de información. El primero de ellos fue la disponibilidad de un bagaje de referencias orientalistas que circulaban en el imaginario colectivo latinoamericano. En segundo lugar, los aportes en esta dirección de los viajeros europeos que circulaban por el espacio americano y atribuían aspectos orientales en sus descripciones de los paisajes y las poblaciones originarias o mestizas del continente, tal como por ejemplo realizó Alexander von Humboldt (1769-1859). En tercer lugar, las noticias del desarrollo de la guerra de independencia griega contra el Imperio Otomano (1821-1829), la cual fue tomada como un enfrentamiento entre la cuna de la civilización occidental y la barbarie y el despotismo asiáticos. Esta concepción cristalizaría y sería la más corriente durante todo el siglo XIX, popularizada por la pluma de intelectuales y patriotas descollantes como Domingo Faustino Sarmiento en su célebre lema "Civilización o Barbarie". Martín Bergel atribuye como principal influencia al respecto las obras de los pensadores de la Ilustración que tuvieron difusión en el Río de la Plata desde principios del siglo XIX, entre los que se destacan Jean Jacques Rousseau (17121778) y Montesquieu, este último, con El Espíritu de las Leyes (Bergel, 2015: 33).

Por otra parte, resulta importante destacar el rol de los viajeros latinoamericanos en el continente asiático, como fue el caso de Francisco de Miranda (1750-1816), para muchos el primer latinoamericano en viajar a Oriente, Lucio Mansilla, Domingo F. Sarmiento, entre otros que viajarían posteriormente. Estos viajeros del continente americano disponían de referencias europeas sobre Oriente tales como las obras de Chautebriand, como Génie du christianisme 
(1802) o Itinéraire du París à Jérusalem (1811), y los escritos de Ernest Renan como por ejemplo Histoire genérale et système compare des langues sémitiques (1855) o Histoire du Peuple d'Israël (1897-1893), y en gran medida reprodujeron las concepciones de aquellos en las apreciaciones que dejaron en los relatos de sus viajes. Hernán Taboada ha denominado a esto "orientalismo periférico" por su dependencia respecto del bagaje cultural europeo y por la marginalidad de dichas producciones en el ámbito cultural occidental. A pesar de ciertas valoraciones positivas respecto de las sociedades orientales, los representantes latinoamericanos se identificaban como cristianos y occidentales en un medio que no lo era (Taboada, 1998: 285-305).

En este sentido, Domingo Faustino Sarmiento buscó el origen de los males americanos en la herencia española, cuya cultura se encuentra mezclada con la árabe compartiendo características de la misma, tales como su inmovilismo por su renuencia al progreso industrial, su despotismo por la vigencia de los privilegios de la realeza, entre otros rasgos propios del orientalismo. A tal punto llega esta caracterización oriental o arabesca de España que Sarmiento propone que esta sea colonizada por otras naciones de Europa que puedan conducirla por la senda de la civilización (De Sena, 2008: 82). Asimismo, Sarmiento entiende que la misión civilizadora de los países europeos en África y Asia resulta necesaria ya que no considera viable la coexistencia con un Oriente bárbaro que se resiste a los avances de la civilización occidental, justificando así la misión imperial europea. De igual manera, utiliza los estereotipos y prejuicios orientalistas para caracterizar a las poblaciones autóctonas y mestizas del continente americano, ya que estas no representan más que parte de la indeseable herencia de la colonización española y las mismas no pueden ser incluidas en el camino de la civilización moderna que propone el pensador sanjuanino. Las referencias orientales en sus escritos son recurrentes, por ejemplo al comparar la llanura pampeana con las planicies asiáticas o en la comparación de los gauchos con los beduinos árabes cuando da a conocer su desprecio por la vida pastoral. Así se expresa Sarmiento:

Esta extensión de las llanuras imprime, por otra parte, a la vida del Interior cierta tintura asiática (...) Y, en efecto, hay algo en las sociedades argentinas que trae a la memoria las soledades asiáticas; alguna analogía encuentra el espíritu entre la pampa y las Ilanuras que median entre el Tigris y el Éufrates; algún parentesco en la tropa de carretas solitarias que cruza nuestras soledades para llegar; al fin de una marcha de meses, a Buenos Aires, y la caravana de camellos que se dirige hacia Bagdad o Esmirna. (Sarmiento, 1971 [1845]: 73).

Y también:

Las hordas beduinas que hoy importunan con sus algaradas y depredaciones las fronteras de Argelia, dan una idea exacta de la montonera argentina (...) La misma lucha de civilización y barbarie, de la ciudad y el desierto existe hoy en África; los mismos personajes, el mismo espíritu, la misma estrategia indisciplinada entre la horda y la montonera. (citado en De Sena, 2008: 78).

Algo que consideramos importante destacar son algunas referencias a la antigüedad que realiza Sarmiento para explicar el porqué de la dicotomía entre la 
civilización y la barbarie. En uno de sus escritos, destacado por Martín Bergel en su investigación, el cual recibe el título de "Resultados generales con que los pueblos antiguos han contribuido a la civilización de la humanidad", refiriéndose a una tesis universitaria de Vicente López, Sarmiento escribe:

Esta investigación encuentra dos filiaciones distintas en que clasificar las diversas civilizaciones; la una es oriental, religiosa, primitiva, inmóvil; la otra occidental, política, de segunda creación, progresista, guerrera. En la primera coloca a la India, el Egipto, la Caldea, la Persia, la Fenicia y sus dos resultados, la Judea y Cartago; en la segunda, la raza pelasga en Asia, Grecia e Italia, luchando, durante muchos siglos, y con diversos nombres, con la rama mayor de la humanidad, con la raza de Sem, con el misterioso Oriente. (Bergel, 2015: 45).

De esta manera se explica el porqué de la oposición entre la civilización y la barbarie, entre Occidente y Oriente, cuyo conflicto se remonta a la mismísima antigüedad, momento primigenio en el que la humanidad toda se dividió en estas dos familias de civilizaciones. Es así que la misma consideración acerca de las sociedades orientales contemporáneas era atribuida también a las sociedades orientales de la antigüedad. La concepción de Oriente representada por Sarmiento que proyectaba una serie de imágenes y tópicos altamente negativos y despectivos fue compartida por sus contemporáneos, razón por la cual Martín Bergel se refiere a la existencia de una matriz orientalista sarmientina. Esta tendrá vigencia durante el resto del siglo XIX y principios del XX e influirá sobre los principales representantes del llamado positivismo argentino, como Carlos Bunge y José Ingenieros.

El positivismo argentino se caracterizó por una puesta en práctica de una suerte de cientificismo, en el que la combinación de las ideas biologicistas sobre selección natural y la difusión de la idea de raza dio origen a un darwinismo social que impregnó los discursos de los intelectuales positivistas y sus representaciones sobre los "otros". A partir de estas ideas se procuró analizar la realidad social argentina y su lugar dentro del concierto de las naciones modernas de fines del siglo XIX con discursos y juicios racistas que culpaban y condenaban a los grupos sociales subalternizados, tales como indios, negros e inmigrantes. Patricia Funes y Waldo Ansaldi han interpretado el uso del concepto de raza por parte de estos pensadores como una herramienta semántica y discursiva capaz de generar un "sentido común" aceptado tanto por las elites dirigentes de los diferentes estados latinoamericanos como por los sectores que resultaban víctimas de dicha estrategia discursiva (Funes y Ansaldi, 1994). La concepción prevaleciente era que se trataba de poblaciones que representaban un obstáculo y un peligro enfermizo para la salud del organismo social argentino. Por ejemplo, Octavio Bunge (1875-1918) califica a estas poblaciones como "plagas", "razas inferiores", y más pormenorizadamente los catalogaba como oportunistas, parásitos, débiles, al punto de asimilarlos a las mujeres (Díaz, 2012: 58).

En este sentido, la posición hegemónica de la llamada Generación del Ochenta reproducirá la antinomia civilización y barbarie, en el marco del culto al progreso establecido por las élites políticas e intelectuales de la Argentina de fines del siglo XIX y principios del XX. Dicha elite de carácter europeizante fue la encargada de reproducir los discursos propios del eurocentrismo y del 
orientalismo. Hugo Biagini ha denominado a esto como el "esquema evolutivo ochentista" construido alrededor de la noción de progreso y sostenido por los diferentes intelectuales de la Argentina de aquel entonces. La noción de progreso se asociaba a otras variables propias de dicho esquema evolutivo, como industrialización y ciencia, y se justificaba así la excepcionalidad de la Argentina en el marco de las naciones latinoamericanas por su mayor europeidad llegando a establecerse vínculos con las culturas clásicas de Grecia y Roma (Biagini, 1995: 12-13). De esta manera también, las poblaciones aborígenes, negras e incluso inmigrantes eran consideradas inasimilables por la nación en ciernes.

La fortaleza de la matriz eurocéntrica y cristiana de la Argentina se manifiesta también en su persistencia a lo largo de la mitad del siglo XX y aún más allá. La noción de pertenencia a la civilización occidental, cuyo estandarte defiende Europa, se expresa en el campo de las ideas acerca de la cuestión de Oriente y su influjo cultural sobre Occidente en los años próximos a la Primera Guerra Mundial, la cual es identificada como una crisis civilizatoria de las naciones europeas (Bergel, 2015: 125-135). Así la segunda parte de la década de 1920 y la década de 1930 verán surgir una férrea oposición a este tipo de lecturas por parte de algunos intelectuales identificados con el nacionalismo católico que expresarían sus ideas en las publicaciones de La Nueva República, Criterio y La Nación. Entre ellos, se destacaron Manuel Gálvez, César Pico, Juan Emiliano Carulla, entre otros. Estos autores enarbolaban las banderas de la defensa de la civilización occidental europea y su herencia grecolatina y cristiana frente al avance de las filosofías e ideas provenientes de Oriente por parte de figuras de los países de Asia como el hindú Rabindranath Tagore o intelectuales europeos como Romain Rolland (Bergel, 2010: 7-26).

Con respecto a las normativas curriculares, por lo indagado hasta el momento, sabemos que las producciones escolares del período estudiado cumplían con un mismo requisito, según el cual se atenían a todos los contenidos mínimos que figuraban en los programas establecidos por el Ministerio de Justicia e Instrucción Pública, ya que todos los libros analizados hacen explícito en sus primeras páginas lo siguiente: "Arregladas al programa de primer año para los Colegios Nacionales, según el plan de estudios vigente", "En él me he ceñido estrictamente al nuevo programa y le he seguido paso a paso, cuestión por cuestión...” (Vera y González, 1901: 4), “Texto único que responde íntegramente a los programas de los colegios nacionales, normales y de ingreso a la facultad de derecho de la Nación" (Racuez, 1926), o también "Adaptado a los programas vigentes en los Colegios Nacionales, Escuelas Normales y de Comercio" (Cabral, 1933).

Hemos consultado hasta el momento los programas escolares correspondientes a los años 1903, 1910, 1940 y 1945 y lo característico de ellos es que los cuatro documentos consultados plantean una serie de contenidos de carácter fáctico que abarcan desde los "orígenes de la Historia" -en términos de la época- hasta la disolución del Imperio romano y los comienzos de la Edad Media, en los cuales se puede observar, aunque no de forma tan explícita, concepciones o representaciones de tipo eurocéntricas. Por ejemplo, en el Plan de estudios y Programas para las Escuelas Normales de la República Argentina del año 1903 
se establece la organización del plan de estudios para la formación de maestros, maestras y mixtas, en el cual la asignatura correspondiente a la historia antigua se encuentra en el tercer año de estudios bajo la denominación de Historia Universal (Primera Parte) con 3 (tres) horas semanales asignadas para su dictado. Dicha asignatura abarcaba los contenidos correspondientes a la antigüedad y la Edad Media. De lo expuesto por el programa conviene citar los primeros contenidos:

El hombre y las razas humanas - Arios y semitas - La Prehistoria. La civilización oriental y la occidental - Primeros focos de civilización.

La civilización oriental - China y el extremo Oriente - La India - Oposición entre la China y la India.

El Oriente clásico de la Civilización Occidental - Egipto: geografía y etnografía - Fases de la civilización egipcia.

Caldea, Babilonia y Asiria - geografía y elementos étnicos - Desarrollo de la civilización en los valles del Tigris y del Éufrates - Carácter de la civilización babilónica con la egipcia.

Fenicios y judíos - Geografía y etnografía - Comercio y colonias de los fenicios Papel que estos desempeñan en la civilización occidental - Los judíos y el sentimiento religioso.

Medos y Persas - Geografía y etnografía - Invasión de los Medos y sus consecuencias - Los persas y la civilización occidental (...)

(...) Las guerras médicas: antecedentes - Maratón - Salamina - Terminación de las guerras médicas - Importancia de esta contienda (1903: 125). ${ }^{3}$

Si se observan las líneas que hemos destacado, se podrá apreciar que si bien se trata de una mera exposición de conocimientos que debieran ser atendidos por el docente a cargo de dicho espacio curricular, en ella afloran expresiones dignas de ser analizadas. En primer lugar, se destaca la existencia de un binarismo compuesto por la civilización occidental y la civilización oriental. Ahora bien, dentro de lo que se entiende por Oriente se diferencian, por un lado, el Extremo Oriente compuesto por las culturas de China e India y, por otro lado, el Cercano Oriente que engloba pueblos como los fenicios, hebreos, medos y persas y el cual es llamado particularmente el "Oriente clásico de Occidente" por su mayor cercanía respecto de la civilización occidental europea en términos geográficos y culturales. En segundo lugar, nótese cómo los diferentes pueblos y culturas son tenidos en cuenta refiriéndose a la importancia de sus aportes respecto de Occidente, tal como el caso de los fenicios y la relevancia de su comercio o el caso de los persas y sus vínculos conflictivos con Grecia. En este último caso, se hace especial énfasis en las guerras médicas entre griegos y persas, lo cual es concebido como el primer enfrentamiento entre Occidente y Oriente. Allí 
radica lo que el programa dispone como la "importancia de esta contienda". Esto mismo puede observarse en el programa de la asignatura Historia Universal en el quinto año del profesorado de letras donde se dispone: "Participación que corresponde individualmente a cada pueblo del Mediterráneo en la formación de la civilización occidental: a) Egipcios; b) Israelitas; c) Fenicios; d) Griegos; e) Cartagineses f) Romanos - El Cristianismo" (1903: 135).

Otro aspecto que sobresale del primer fragmento citado es la referencia al concepto de razas, que era por aquel entonces moneda corriente para realizar la clasificación de pueblos y culturas de acuerdo a sus características peculiares y su grado de desarrollo civilizatorio en términos claramente evolutivos, como podremos observar al analizar los libros de texto correspondientes. Este concepto se reitera en los diferentes programas a lo largo del tiempo, tal es así que en el Programa de Historia para los Colegios Nacionales de 1940 la Unidad I es presentada con los siguientes contenidos:

I - La Historia; su objeto y sus fines. - Fuentes - Ciencias auxiliares de la Historia.

- Los grandes periodos históricos. - Los tiempos prehistóricos: edad de piedra, del bronce y del hierro. - Las razas. - El medio geográfico y su influencia sobre los pueblos y los acontecimientos históricos. (1940: 3)

Como puede observarse, la organización de los programas de la asignatura Historia Universal, ya se trate de los colegios nacionales, comerciales o de las escuelas normales, responde a un claro interés por conocer las diferentes culturas de la antigüedad, siempre atendiendo a los aportes y a las relaciones de estas para con la civilización occidental. Asimismo, la presentación de los contenidos históricos se realiza desde una perspectiva esencialista que propone explicar el devenir histórico a partir del binarismo Oriente-Occidente, entendido este como una relación inherentemente conflictiva, y también de carácter evolucionista ya que concibe a la civilización occidental europea como la cima del desarrollo histórico. Podríamos decir que estamos en presencia de una matriz cultural a todas luces eurocéntrica.

\section{El eurocentrismo y el orientalismo en los libros de texto del período 1890-1950}

Los escritores de dichas obras escolares eran docentes del Colegio Nacional Buenos Aires, como el capitán N. A. De Vedia, el Dr. Jerónimo Peralta o el Dr. Vicente Racuez, e incluso docentes y consejeros de la Universidad de Buenos Aires, como el Dr. Jorge Cabral. Es importante destacar que en la Argentina de fines del siglo XIX y principios del siglo XX no existía aún un campo de estudios académicos propio de la historia antigua oriental, sino que este irá madurando durante toda la primera mitad del siglo, en gran parte debido a los trabajos e investigaciones de Abraham Rosenvasser (1896-1983), quien fuera docente del Colegio Nacional de la Plata, el Instituto Nacional del Profesorado, la Universidad Nacional de La Plata y la Universidad de Buenos Aires (Rosso y Daneri, 1999). 
Es importante resaltar la colaboración en algunas de estas producciones escolares de intelectuales europeos de gran reconocimiento como el egiptólogo Alexandre Moret, profesor del Colegio de Francia, y Arduino Colasanti, profesor de la Universidad de Roma. En el libro de la editorial Estrada de 1933, Moret escribe el capítulo referido a Oriente y Colasanti el referido a Roma, los cuales son traducidos al español por el profesor Jorge Cabral, quien a su vez es autor del capítulo correspondiente a la Grecia antigua. La actualización de los contenidos de historia antigua se produce de esta manera, a partir del diálogo con intelectuales y las obras de los países europeos más adelantados en términos de producción historiográfica respecto de la historia de la antigüedad. En este sentido, resulta importante analizar el discurso y los argumentos de una carta fechada en 1926 que Alexandre Moret escribe a Tomás E. Estrada respecto del pedido a participar en el libro mencionado anteriormente. Al respecto, Moret procura justificar la relevancia de la enseñanza de la historia de dichas sociedades y presenta una serie de temáticas que deberían ser abordadas por los docentes. En dicha exposición algunos elementos propios del eurocentrismo se dejan traslucir, por ejemplo, en la interpretación de las relaciones entre pueblos nómades y sedentarios, entendidas como inherentemente conflictivas, considerando bárbaros a los primeros y civilizados a los segundos. Respecto de esto y de su interés por parte de los estudiantes argentinos, sostiene que:

Los estudiantes del Nuevo Mundo comprenderán esta fatalidad histórica tanto más, cuanto que tienen cerca de ellos un ejemplo de esta rivalidad entre nómades y sedentarios bajo el aspecto de la lucha por la posesión del suelo entre colonizadores llegados del antiguo continente, y las poblaciones autóctonas, degeneradas casi hasta el estado nómade. (citado en Cabral, 1933: 9).

Tras su razonamiento lo que se hace presente es la idea de que las poblaciones originarias de América eran bárbaras y los europeos portadores de la civilización, justificando por ello la misión colonizadora en el continente americano. Por último, como reflexión final de su carta Moret arguye que tanto el Viejo Mundo como el Nuevo Mundo han recibido las aportaciones de la civilización oriental ya extinta a través del legado que las culturas griega y romana nos han heredado en cuanto cuna de la civilización occidental. En palabras del autor:

La conclusión que el profesor deberá poner en evidencia es que, a través de todas esas transformaciones tan amplias, la antigua civilización oriental no desaparece por entero. Por el contrario, ella entra en contacto con la civilización helénica y romana, la fecunda con sus múltiples contribuciones, le transmite sus instituciones imperialistas, sus filosofías, su misticismo, y finalmente se impone al mundo entero mediante el Cristianismo. Su influencia secular se deja sentir aún entre nosotros, latinos del Nuevo y del Viejo Mundo, herederos todos de los griegos y de los romanos, instruidos ellos mismos por la sabiduría oriental. ¿No es esta acaso la justificación de la enseñanza de la historia del antiguo Oriente? (citado en Cabral, 1933: 10).

Dichas palabras cumplen la función de incluir a los países del continente americano dentro del marco de la civilización occidental y cristiana. Los autores argentinos se jactan de ello y lo dejan traslucir en los discursos de sus obras. 
Ahora bien, para realizar el abordaje de los libros de texto seleccionados hemos delimitado una serie de ejes o variables que articulan y ordenan el análisis, siendo estos los siguientes: la clasificación racial y civilizatoria; las apreciaciones sobre la historia del antiguo Egipto; la importancia atribuida al pueblo hebreo; la valoración respecto del Cristianismo; la relación entre Oriente y Occidente; las valoraciones expresadas acerca de la historia de las sociedades del antiguo Oriente y el análisis del binarismo masculino-femenino.

Con respecto a la primera variable de análisis, uno de los principales conceptos que se utiliza en los primeros capítulos de la mayor parte de los libros es el de raza, el cual sirve a los fines de caracterizar las diferentes poblaciones o grupos humanos desde los orígenes de la historia hasta el presente. Siguiendo a la antropóloga Claudia Briones, la concepción racial asociada a las diferencias congénitas entre grupos humanos tiene un punto de partida el cual se ubica en el siglo XVIII en un contexto europeo de creciente racialización de la cultura y que será utilizada por las elites blancas americanas para diferenciarse de las poblaciones indígenas y negras (Briones, 1998: 26). En este sentido, en el manual cuya autoría pertenece al profesor Jerónimo Peralta, el cual se titula Historia de las Civilizaciones Antiguas de 1916 se plantea la siguiente clasificación de las sociedades en razas: "Con el nombre de raza se denomina cada uno de los cuatro grandes grupos en que se considera dividida a la especie humana atendiendo a sus diferencias de estatura, facciones, cráneo, color, lengua, sentimientos e inteligencia."(Peralta, 1916: 34). Como puede observarse, la clasificación en grupos raciales se encuentra atravesada por la cuestión de la moral y su adaptabilidad al progreso, por lo cual estamos en presencia de una concepción de la historia universal evidentemente evolutiva y propensa a establecer el modelo europeo como cúspide de esa evolución progresiva. Pero pasemos a analizar dicha clasificación racial tal como lo expresa el libro de texto en cuestión:

Por sus caracteres físicos y morales, los pueblos han sido agrupados en cuatro razas: blanca, amarilla, negra y cobriza o americana.

La raza blanca, superior a todas las demás, por sus manifestaciones morales e intelectuales y por la grandeza de los progresos realizados y su mayor capacidad para concebir y obrar, tiene el cetro del mundo. Su cuna fueron los montes caucásicos que se extienden entre el Mar Negro y el Mar Caspio, o los valles del Indo y del Ganges, al pie de los nevados Himalayas, según otros. Por eso se llama caucásica una veces y aria otras. (Peralta, 1916: 36).

Las teorías racistas en las que se apoyan estas argumentaciones del autor parecen corresponderse con las de Carl Linnaeus (1707-1777) o Johann Blumenbach (1752-1840), las cuales se destacan por considerar que las características físicas y mentales se correlacionan entre sí y que son transmitidas genéticamente o por gracia divina pero que resultan inalterables. Una de las particularidades de estas teorías es la de presentar el tamaño de los cráneos como una evidencia de la superioridad intelectual en lo que se da a llamar craneometría, a la que luego se le sumó la antropometría, es decir, el estudio y la medición de los huesos (Martinelli, 2010: 1079-1089). Este tipo de análisis se encuentran en los textos escolares analizados, particularmente el de Vicente Racuez y el de Jerónimo Peralta. No está de más decir que la descripción del resto de las razas, especialmente de la negra, es altamente despectiva, como podremos notar a continuación: 
La raza negra es menos inteligente y moral que las anteriores; pueblos hay que son incapaces de progreso alguno y cuyo nivel intelectual es tan bajo que no se diferencia sino muy poco del de los monos. Es la raza más inferior y puebla el centro y mediodía del África y algunas islas de Oceanía. Sus ramas principales, según su orden intelectual, son la etiópica, cafre y hotentote. (Peralta, 1916: 37).

Como podemos ver, la raza negra es la contracara de la blanca, aria o caucásica, lo que podríamos interpretar, ateniéndonos a la ideología eurocéntrica, como la justificación de su dominación y explotación. Este tipo de racialismo nos remonta a los planteos de Gobineau, aunque también de Buffon y Voltaire, sobre la superioridad de la raza blanca y la inferioridad de la raza negra, al punto de rozar la animalidad (Todorov, 1991: 115-127). De manera similar, el libro de texto de Vicente Racuez denominado Historia de la Civilización de 1926, expresa en sus páginas respecto de las razas:

Las razas, por tanto, que más han trabajado en la cultura y el progreso, son la raza blanca, y en algún grado, la china o amarilla, quedando la negra, hasta nuestros días, en un estado de postración y aniquilamiento, que apenas le distingue de los tiempos primitivos. (Racuez, 1926: 22).

Este tipo de aseveraciones nos remiten a los pensadores positivistas argentinos quienes expresaban valoraciones despectivas de la raza negra similares a estas, lo cual se debe al parecer a que se comparte el mismo uso, significado y funcionalidad del concepto de raza. Esto, además puede interpretarse, como lo ha hecho Martín Díaz en un reciente artículo, en términos de un racismo epistemológico consolidado en las ciencias humanas europeas que postulaban una racionalidad moderna capaz de asumir una distancia epistemológica respecto de todo lo existente y por ello generadora de representaciones y estereotipos de las poblaciones no europeas consideradas como un objeto de estudio detenido en el tiempo (Díaz, 2017: 7). El autor rastrea dicho racismo epistémico en representantes de la filosofía moderna tales como Immanuel Kant (1724-1804) y David Hume (1711-1776) y, siguiendo a Enrique Dussel y Aníbal Quijano, propone la consolidación de una matriz colonial epistemológica de carácter occidentalocéntrica. Además, en estrecha relación al concepto de raza se sitúa el de civilización, por lo cual se entiende que la raza blanca dio origen a las primeras y más desarrolladas civilizaciones. Así se lo expresa en el libro de Jerónimo Peralta:

Definidos los caracteres de las razas, compréndase que la civilización debió comenzar en los pueblos de raza blanca. Los Arios y los semitas que pertenecen a ella iniciaron la civilización humana en épocas muy lejanas al comienzo de nuestra Era (...). (...) Los arios y los semitas son troncos de donde provienen los pueblos actuales. Así son de origen ario los persas, indios, griegos, latinos, germanos, escandinavos, celtas y eslavos; de origen semita los árabes, judíos y sirios. (Peralta, 1916: 38-39).

Como señalábamos anteriormente, existe una asociación entre la idea de civilización y los pueblos blancos o arios, ya que la misma se habría originado en ellos mismos, entre los que se incluye tanto a los persas como a los griegos, quienes luego serán también diferenciados por el autor en cuanto a su desarrollo 
moral y civilizatorio. Este tipo de aseveraciones se basaban en una supuesta cientificidad brindada por la lingüística del siglo XVIII en adelante, la cual oponía artificialmente a los pueblos indoeuropeos como garantes de la libertad y la razón a los pueblos de lenguas semitas proclives a la servidumbre y al despotismo (Amin, 1989: 91; Todorov, 1991: 176-177).

En cuanto a la segunda variable de análisis, tal como lo expresa Martin Bernal, la instalación del denominado modelo ario implicó la negación de todo vínculo de influencia y de interacción entre la cultura griega y las culturas egipcia y fenicia. Ya en tiempos del medioevo los promotores del cristianismo se encargaron de denostar a la religión egipcia, negándole incluso el título de religión y en el siglo XVIII al calor de las ideas racistas y del auge de la noción de progreso comenzaron los ataques sobre las culturas egipcia, fenicia y china, degradadas estas a una concepción de prehistóricas, tildadas de estériles e inmóviles. De esta manera, la cultura griega era entendida a partir de una suerte de autogénesis, es decir, producto de un proceso sin ningún tipo de mezcla o préstamos culturales o raciales.

No obstante, uno de los textos analizados sostiene la vinculación de la cultura egipcia con otras civilizaciones orientales, como la fenicia, y que a partir de ella su influencia habría llegado a Grecia. Esto último se contrapondría excepcionalmente aquí con la concepción del modelo ario radical que plantea Bernal en Atenea Negra, el cual negaba todo tipo de influencia asiática o africana. Dice el texto de Racuez: "La Fenicia recogió la civilización egipcia, y la comunicó por el comercio a los otros pueblos: la Grecia recibió del Egipto los primeros elementos de su cultura y civilización, que después comunicó a los romanos" (Racuez, 1926: 36). Egipto es considerado de esta manera como una civilización superior que es aceptada en la genealogía de la civilización occidental a partir de la influencia de su herencia sobre la cultura griega. En este sentido, se destaca en las palabras de estos autores la supervivencia de dicha civilización en ciertos aspectos de las culturas griega y romana:

La nobleza y la elevación de su ideal religioso constituyeron la admiración de Platón; en Grecia y Roma, muchos grandes talentos se hicieron iniciar en los misterios de la religión de Osiris que pretendía vencer a la muerte. Los misterios de Isis, que tuvieron gran boga en Roma, prepararon el camino al cristianismo. El mundo antiguo debió, no solo muchos progresos materiales sino también sus primeras lecciones de sabiduría y de justicia, sus primeras nociones de responsabilidad y de conciencia y sus primeras esperanzas en una retribución celeste, a la que los griegos denominaban: "La madre de las civilizaciones”, a la civilización egipcia. (Cabral, 1933: 145).

Apreciaciones de este tipo se encontraban ya presentes en el análisis del antiguo Egipto realizado por N. A. De Vedia en su libro de 1893, donde se planteaba que: "De todo esto heredó la Grecia; ella lo sabía y se confesaba discípula de Egipto; de manera que aquel faro esplendente de la civilización helénica, había sido encendido con fuego traído de las riberas del Nilo" (De Vedia, 1893: 85). Pareciera existir entonces una consideración de Egipto como una civilización de gran importancia en el devenir de la humanidad, la cual incluso habría contribuido a la formación de la civilización griega y romana y por ello habría realizado 
importantes aportes a la civilización occidental. No obstante, es una contribución de manera indirecta, sistematizada por la cultura griega, sin la cual nada de lo anterior hubiera sido posible. Por ello, de Egipto sólo queda un pasado glorioso representado por sus construcciones monumentales y ya nada tiene que ver con el presente cuya hegemonía corresponde a la civilización occidental y cristiana.

Con respecto a la tercera variable de análisis, el "pueblo" hebreo ocupa un lugar singular en dichos libros escolares y en la historia de la construcción de Occidente al representar una suerte de vínculo entre Oriente y Occidente. ${ }^{4}$ Como expresa Emanuel Pfoh, el Oriente antiguo fue concebido como el lugar de origen de las narrativas bíblicas del Antiguo Testamento, las cuales expresaban el origen y la historia del pueblo de Israel. Esto resultaba fundamental para los intelectuales europeos ya que simbolizaba los orígenes del cristianismo y la legitimación de la expansión europea por el mundo. En este sentido, la historiografía decimonónica y del siglo XX le concedió un lugar de privilegio a la Biblia considerándola como un documento histórico a partir del cual reconstruir la historia del pueblo de Israel, entendido este último según la concepción de los estados nacionales europeos (Pfoh, 2010: 690). Pasemos a analizar qué se decía acerca de los hebreos en los libros de texto que venimos analizando. Por ejemplo, en el libro de Vicente Racuez se expresa:

La civilización debe al pueblo hebreo la conservación de la unidad de Dios, y, como consecuencia, la unidad de la especie humana, la igualdad y la fraternidad de todos los hombres, y en su complemento, la caridad. Pero, además de esto, la humanidad le estará eternamente agradecida por haber nacido allí Jesucristo, el Salvador del mundo. (Racuez, 1926: 42-43).

La obra de Racuez presenta este tipo de valoraciones en favor de la religión cristiana que nos estarían mostrando una fuerte y arraigada matriz cristiana que se expresa en la prosa del autor en cuestión. Con el mismo tono de exaltación y de admiración en el libro de texto de N. A. De Vedia se expresa: "Del seno del pueblo de Israel brotó la viva llama, que al encender en el alma humana una nueva fe y una nueva esperanza, la retempló para otra etapa en la áspera cuesta del progreso y la hizo mejor; la Grecia misma no ha hecho tanto." (De Vedia, 1893: 198-199). Otros autores, como Jorge Cabral, coinciden en este diagnóstico y valoración de la historia de los hebreos destacando, por ejemplo, la importancia de la Biblia como una fuente para conocer la historia de los pueblos antiguos y en particular la de los hebreos:

Aparte de su valor histórico, la Biblia es para el observador un documento precioso, pues puede seguir en ella las etapas de evolución de los israelitas de la vida pastoril hasta la vida civilizada, y reconocer instituciones comunes a los pueblos primitivos. La historia de Oriente se presenta como una serie de choques y reacciones entre pueblos nómades y sedentarios, entre civilizados y bárbaros que llegan a amenazar

4 Actualmente la noción de "pueblo" hebreo ha perdido el significado absoluto que tenía hace un siglo. Hoy se habla de poblaciones semitas que hablaban y escribían en lengua hebrea durante el primer milenio a.C., pero ya no de una homogeneidad étnica como sugeriría el concepto de "pueblo hebreo". Comunicación personal con E. Pfoh. Véase al respecto Sand (2011: 77-144). 
y a veces hasta destruir las civilizaciones. Los detalles proporcionados por la Biblia permiten tomar a los hebreos como ejemplo típico para ilustrar este pasaje de la vida nómade a la vida civilizada. (Cabral, 1933: 247-248).

Se desprende de este fragmento una clara concepción esencialista de la historia en general y en particular de la de Oriente, a partir del planteo de los binarismos nómade-sedentario y barbarie-civilización propios de un discurso eurocéntrico. $\mathrm{Y}$ a partir de estos esquemas es posible situar a los hebreos dentro de los marcos de la civilización. En suma, la importancia adjudicada a dicho pueblo se resume en la emergencia del monoteísmo que se produjera en su seno y su estrecha relación, continuamente resaltada en la prosa de los escritores analizados, con la religión cristiana que viera la luz en la antigua Roma.

En cuanto a la cuarta variable de análisis, vale destacar que la importancia atribuida al pueblo hebreo, por ser este el seno de la aparición del monoteísmo, cobra mayor relevancia cuando se establece un vínculo entre este fenómeno religioso y la emergencia del cristianismo, el cual es tomado como uno de los elementos constitutivos y superadores de la civilización occidental. Racuez lo expresa de la siguiente forma:

La antigüedad gemía bajo el peso de la desigualdad nacida del politeísmo (...). Jesucristo, predicando la unidad de Dios, y la consiguiente igualdad de las criaturas, vino a redimir a tantos desgraciados, levantándolos de su miserable estado, y dignificándolos con el santo nombre de hermanos en Dios. Desde entonces existe la fraternidad humana en la tierra; tardará más o menos tiempo en abrirse paso en las conciencias, en realizarse en la vida; pero la semilla está arrojada, y más tarde o más temprano dará sus frutos, y la gloria de tan grandioso resultado pertenece por completo al Cristianismo. (Racuez, 1926: 179-180).

Se expresa el contraste entre la naturaleza de las religiones de Oriente signada por el politeísmo y el paganismo y el punto de quiebre que representa el surgimiento del evangelio de Jesucristo y del cristianismo. Puede observarse la matriz cristiana en la cual se encuentra inmerso el autor y su situación en calidad de creyente. La concepción evolutiva de la historia universal toma aquí a la religión como uno de los parámetros a partir de los cuales juzgar a las culturas y pueblos y de allí se desprende un juicio despectivo sobre las sociedades de Oriente. Plantea Racuez:

La antigüedad desarrolló por completo la idea religiosa en el Oriente, y desenvolvió la unidad de Dios en el pueblo hebreo, alcanzando esta su complemento y perfección en la doctrina de Jesucristo, enseñada por la Iglesia: desenvolvió la idea de libertad aplicada a casi todos los fines humanos por la Grecia; y realizó la idea social por Roma. El Oriente nos ha enseñado el conocimiento de Dios, Grecia el conocimiento del hombre, y Roma el conocimiento de la sociedad. (Racuez, 1926: 181).

Debemos relacionar esto con la matriz cristiana que existía en la Argentina desde los tiempos coloniales y que se expresa en los discursos de los intelectuales decimonónicos como Sarmiento, y ya en el siglo XX, solapadamente, en los representantes del positivismo argentino y del nacionalismo católico. 
Con respecto a la quinta variable de análisis, como expresábamos anteriormente, el eurocentrismo ha procurado legitimarse buscando los orígenes de Occidente y Europa en la antigüedad griega. De esta manera entonces, se procuró establecer el inicio del binarismo Oriente y Occidente contraponiendo dos culturas y civilizaciones de la antigüedad, tales como los persas y griegos, cuyo punto culminante es identificado con las Guerras Médicas (490-478 a.C.). Dicho conflicto es concebido como un aspecto transversal de la historia y sería reeditado en diferentes momentos históricos. Tal como lo expresa Mario Liverani, el paradigma denominado Ex Oriente Lux ("Del Oriente viene la Luz") es acompañado por el del "milagro griego" y sostiene al respecto que los intelectuales europeos interpretaron la guerra de independencia griega contra el Imperio Otomano como una reedición de las Guerras Médicas. La relación entre Europa y Oriente fue presentada entonces a partir de una serie de opuestos tales como: libertad vs servidumbre; democracia vs despotismo; progreso vs estancamiento; racionalidad vs misticismo; ciencia vs magia, etc. (Liverani, 1999: 5). Ahora bien, ¿qué dicen los libros de texto del período seleccionado de las Guerras Médicas? Citamos aquí un ejemplo:

...las Guerras Médicas pueden ser consideradas como una de las tantas fases que presenta la lucha secular entre Oriente y Occidente, continuada, a través de la historia, a través de todas las edades, hasta nuestros tiempos. Con las Guerras Médicas es la primera vez que esta lucha va a presentarse con el aspecto de una guerra organizada en la que triunfaron el talento sobre la fuerza, el genio de la libertad sobre el genio del despotismo. En las Guerras Médicas podemos ver también el espíritu de Oriente, místico y servil, cuyos dioses terroríficos no admiten dividir el mundo con los bellos y humanitarios dioses griegos. La civilización va a ganar en este duelo tremendo de dos razas y dos religiones, porque se va a rasgar el velo que les impedía conocerse. El deseo de independencia dará el triunfo a los griegos. (Peralta, 1916: 240).

Tal como decíamos anteriormente, el conflicto entre Oriente y Occidente es entendido como secular e inherente a la relación entre estos espacios. La contraposición entre los griegos y persas no es otra cosa que la traspolación de las oposiciones entre Europa y Asia y entre civilización y barbarie propuestas por el eurocentrismo. Esto mismo es expuesto por Jorge Cabral en sus textos al presentar el conflicto:

Se llaman Guerras Médicas las que sostuvieron los persas medio siglo con los griegos, quienes solo pudieron vencer gracias a su valor y a su espíritu de libertad. En realidad, si la guerra de Troya es el primer episodio, las Guerras Médicas, que pueden Ilamarse también guerras por la libertad, son el segundo acto de la lucha entre el mundo asiático y europeo, lucha que aún no ha terminado.

Cincuenta años debieron combatir los griegos contra el poderío persa para salvar la grandeza de sus instituciones y la independencia de su territorio, y al estudiar las causas de esta larga contienda, se observará que el choque no es entre dos pueblos, sino entre dos civilizaciones; la lucha no es entre griegos y persas, sino entre asiáticos y europeos. (Cabral, 1950: 179).

Las Guerras Médicas entre griegos y persas representaron solamente uno de los capítulos en la historia de enfrentamientos entre Oriente y Occidente. La cultura 
griega, recogida y asimilada por los romanos permitió a la civilización y cultura griegas perdurar a lo largo del tiempo. Por estas razones, Roma representa los valores del legado griego y es el representante exclusivo de Occidente en los conflictos de su época con otras civilizaciones, como por ejemplo Cartago. Las valoraciones distintivas proyectadas sobre los griegos y persas durante las Guerras Médicas aquí vuelven a reiterarse bajo estos nuevos protagonistas. Por ejemplo, respecto de los cartagineses se plantea el siguiente juicio: "Pueblo bárbaro envilecido por el oro y la lujuria. Cartago estaba destinado a perecer en la lucha con Roma” (Peralta, 1916: 385).

En este sentido, como ya planteamos anteriormente, se sitúa el conflicto en un marco más general entre dos razas, tales como arios y semitas, e incluso entre las dos partes en las que se divide el mundo: Oriente y Occidente. Recordemos la correspondencia de estas afirmaciones con los planteos de Ernest Renan acerca de las razas lingüísticas. Así se lo presenta en uno de los libros de texto:

\begin{abstract}
En la antigüedad dos razas se disputan el Imperio de la tierra, arios y semitas. Ya hemos visto con que tesón lucharon en Oriente; primero caldeos yasirios, después egipcios y judíos, griegos y persas, y, por último, cartagineses y romanos. Es siempre el espíritu de Oriente contra el espíritu de Occidente; dos formas de civilización con ideales distintos. Así se explica cómo es tan celebre esa lucha entre Cartago y Roma; de haber triunfado la primera, todas las bellas conquistas del genio ario hubieran desaparecido; hoy no sabríamos nada de poesía, teatro, escultura y otras manifestaciones del arte griego, ni menos del romano. Pero venció Roma y la civilización de occidente pudo continuar su progreso. (Peralta, 1916: 385$)^{5}{ }^{5}$
\end{abstract}

De forma similar, el libro de Benito Sarthou del año 1932 sostiene: "Roma representaba en esa hora el vigor insospechado de una joven raza occidental, irguiéndose con grandes probabilidades de victoria frente a la heredera de fenicia y de la civilización asiática" (Sarthou, 1932: 445). Así la importancia de Roma habría sido la de salvaguardar el legado de la cultura griega y todos los valores atribuidos a esta. Se podría interpretar que mientras Grecia es valorada como la cuna de la civilización occidental, Roma es apreciada en tanto que defensora de esos orígenes y porque esta es entendida como la cuna del cristianismo. Los manuales de la época estudiada, fuertemente influidos por una matriz cristiana, dejan ver esto, por ejemplo, en el siguiente párrafo sobre la importancia del papel de Roma en la historia universal: "Así le cupo a Roma el grandioso destino de ser la educadora de los pueblos occidentales, el de transformarse luego en gloriosa capital del mundo cristiano y merecer, por fin, el nombre consagrado de Ciudad Eterna" (Sarthou, 1932: 413). ${ }^{6}$

En lo referido a la sexta variable de análisis, en las apreciaciones de la historia de Oriente uno de los tópicos permanentes y transversales en las obras es el del despotismo oriental, es decir, como ya hemos descripto, regímenes de tipo absolutista en los cuales el soberano concentra la totalidad del poder y lo usa de forma desmesurada para someter a sus súbditos. El máximo

5 El destacado corresponde a la obra original.

6 El destacado corresponde a la obra original. 
representante del despotismo de los pueblos orientales es el imperio persa, el cual es tomado como antítesis de las sociedades griegas, principalmente ateniense, y su sistema democrático durante el siglo V a.C. Vicente Racuez plantea al respecto "Desde Ciro reviste la monarquía persa un carácter despótico, inherente a los pueblos orientales" (Racuez, 1926: 43). También en otro momento plantea: "En cuanto al gobierno la forma más general fue el despotismo, reuniendo los monarcas todos los derechos y representando a Dios en la tierra" (Racuez, 1926: 45). Así también, Oriente es considerado la infancia de la humanidad, un primer eslabón en la cadena de la evolución histórica y se explica a partir de ello su inferioridad respecto de Europa. Racuez lo presenta de la siguiente manera:

De cuanto hemos expuesto, resulta que la humanidad debe al Oriente, como el hombre debe a su niñez, el ejercicio inconsciente de todas sus aptitudes, el desarrollo de sus primeras ideas, y de los primeros gérmenes de su vida y de su civilización futura. La religión y el gobierno, la ciencia y la literatura, las artes y la industria, el comercio y la agricultura, todo en fin, lo que constituye la vida de la humanidad, tiene allí sus comienzos y sus primeras evoluciones. La humanidad, que en los tiempos prehistóricos había aprendido a vivir, segura ya de la existencia, comienza en el Oriente el aprendizaje de la civilización. (Racuez, 1926: 47).

Los argumentos del autor nos remontan de manera directa a las afirmaciones de Hegel respecto de que la historia universal nace en Oriente y la adultez corresponde a Occidente. En palabras de Hegel (1997: 201): "La historia universal va de Oriente a Occidente. Europa es absolutamente el término de la historia universal. Asia el principio". Asimismo, como lo expresa Pfoh, los argumentos de Hegel sirvieron posteriormente de legitimación filosófica del imperialismo y el colonialismo europeo (Pfoh, 2013: 117-118). Tal como lo expresaba el enunciado Ex Oriente Lux, de Oriente proviene la luz de la civilización, pero sólo su comienzo; las culturas griega y romana, representantes de Occidente en la antigüedad, serán las verdaderas encargadas de llevar esta a su máxima expresión como primigenios representantes de Europa. Por ello, Racuez sostiene de forma comparativa y antagónica que "Por brillantes que fuesen en apariencia los imperios asiáticos, eran, en realidad, bien inferiores a un pequeño Estado de Europa: la Grecia. Los griegos fueron los más instruidos de los hombres, los que tuvieron ciudades más cultas y gobiernos más libres" (Racuez, 1926: 48).

Con respecto a la séptima y última variable de análisis, el binarismo masculino-femenino es una de las dimensiones constituyentes del eurocentrismo, entendiendo lo masculino como ontológicamente superior a lo femenino, aun entre los pueblos o culturas no occidentales. A su vez, uno de los tópicos o estereotipos propuestos por el discurso del orientalismo corresponde a la sensualidad inherente a las mujeres asiáticas, que se extiende a la práctica de una sexualidad desenfrenada de todos los orientales; prácticas inmorales que operan como una amenaza de degeneración de las costumbres morales y mesuradas de los griegos en la antigüedad y de los europeos en la modernidad. También en este campo se plantea la superioridad de las mujeres griegas respecto de las asiáticas, tanto en sus comportamientos como en su rol social. El texto de Racuez dice al respecto: 
Entre los griegos la familia tiene una constitución distinta que en los pueblos de oriente. La sumisión ciega e incondicional de todos sus miembros al jefe no existe; la mujer tiene derechos y el hijo también los tiene, no obstante el respeto que siempre se debe al padre. Tampoco se conoce la poligamia, las esposas no viven relegadas como entre los asiáticos, sino que gozan de casi amplia libertad, y el hombre cuando elige mujer debe dotarla, con lo que se le asegura el porvenir en caso de divorcio. La mujer griega es muy respetada aun cuando no siempre sea un dechado de virtudes como Elena, Clitemnestra, Antea y otras; pero es que los hombres son demasiado indulgentes (...). Así como se educa al varón para los trabajos de la vida y para la guerra, la mujer es educada para los trabajos domésticos, y ni las mismas hijas de los reyes dejan de ejecutarlos. (Racuez, 1926: 161).

He aquí un análisis binario, que contrapone la situación de la mujer griega a partir de establecer comparaciones despectivas respecto de las mujeres asiáticas. En Oriente se evidencia la práctica de la poligamia mientras que en Occidente no es así; en Grecia la mujer tenía derechos, aunque no fuera igual al hombre y estas debieran ser controladas, mientras que en Oriente no; en Grecia la familia respeta a su padre y esposo pero no ciegamente ya que esa es una característica de las sociedades orientales que parecieran encontrar ya en la familia la obediencia necesaria para vivir luego bajo monarcas despóticos. Vale aclarar que la idea de que las mujeres asiáticas se encontraban pasivamente recluidas en el ámbito doméstico sin participación en la vida pública parece más propia del tiempo presente en el que escribe el autor y en el cual contempla despectivamente el Oriente contemporáneo signado por el dominio del Islam.

Por último, en el discurso del orientalismo, lo femenino muchas veces aparece encriptado en lo masculino, distorsionando esta última cualidad. Aun los hombres orientales son representados con rasgos femeninos y por supuesto los representantes de Occidente que se han orientalizado, tal como Alejandro Magno, cuyo caso no hemos analizado en el presente artículo, que adquirió las prácticas orientales más reprochables, tales como la promiscuidad, la desmesura y el ejercicio despótico del poder. Tal como ha sostenido la socióloga japonesa Chizuko Ueno, tanto las mujeres orientales como el mismo Oriente son una creación del discurso masculino occidental, el cual proyecta la figura del otro sobre ambos, a lo que agrega que las mujeres son para los hombres lo que Oriente es para Occidente. No obstante, la autora aclara que si bien los varones orientales también son considerados por el discurso del orientalismo como afeminados, las mujeres son consideradas doblemente afeminadas y por ello doblemente inferiores. Es más, los hombres orientales utilizan dicha concepción de la feminidad en sus propios discursos (Ueno, 2001: 158-159).

\section{Conclusiones}

En la presente investigación hemos intentado demostrar que la historia antigua de las sociedades de Oriente, de la civilización griega y la cultura romana, se encuentra teñida, en los libros de texto analizados, por los prejuicios y representaciones del eurocentrismo y el orientalismo. Asimismo, hemos encontrado 
una fuerte coincidencia entre los juicios establecidos por los autores de los libros de texto de la antigüedad y muchos de los discursos sostenidos por los intelectuales eurocéntricos argentinos de fines del siglo XIX y de la primera mitad del siglo XX que enaltecían los ideales civilizatorios europeos, occidentales y cristianos. Desde Sarmiento, los positivistas argentinos y los intelectuales nacionalistas católicos de la segunda mitad de la década de 1920 y de los años treinta, se denota la existencia y la persistencia a lo largo de todo el periodo estudiado de una matriz de pensamiento occidental, eurocéntrica y cristiana. Es dentro de esta matriz que deben entenderse las interpretaciones propuestas por los autores de los libros de texto abocados a la difusión y la enseñanza de la historia antigua. Para las élites políticas e intelectuales de Argentina la antigüedad importaba en tanto y en cuanto a partir de la misma se podía justificar su pertenencia a Occidente y su civilización. 


\section{Q Bibliografía}

\section{Bibliografía primaria}

»Cabral, J., Moret, A. y Colasanti, A. (1933). Manual de Historia Antigua. OrienteGrecia-Roma (Cuarta Edición). Buenos Aires: Editorial Estrada.

"Cabral, J., Moret, A. y Colasanti, A. (1950). Grecia. Buenos Aires: Editorial Estrada.

»De Vedia, N. A. (1893). Historia Antigua (Oriente). Buenos Aires: P. Igon y Cía. Editores.

»Peralta, J. (1916). Historia de las civilizaciones antiguas. Oriente, Grecia, Roma (segunda edición). Buenos Aires: Librería de Ángel Álvarez.

"Plan de estudios y programas para las escuelas normales de la República Argentina (1903). Ministerio de Justicia e Instrucción Pública, Buenos Aires.

"Programas de historia para los colegios nacionales (1910). Ministerio de Justicia e Instrucción Pública. Buenos Aires: Talleres gráficos de la Penitenciaría Nacional.

»Programa de historia para los colegios nacionales (1940). Ministerio de Justicia e Instrucción Pública. Buenos Aires: Peuser.

»Programa de historia para los colegios nacionales (1945). Ministerio de Justicia e Instrucción Pública. Buenos Aires.

"Racuez, V. (1926). Historia de la Civilización. Buenos Aires: Librería Sopena.

» Sarmiento, D. F. (1971). Facundo. Buenos Aires: Kapelusz.

»Sarthou, B. (1932). Historia antigua. Oriente, Grecia y Roma. Buenos Aires: Poblet Hermanos Editores.

»Vera y González, E. (1901). Nociones de Historia Universal de las edades Antigua y Media. Buenos Aires: Cabaut y Ca. Editores.

\section{Bibliografía secundaria}

»Abdel-Malek, A. (1963). Orientalism in Crisis, en: Diógenes 11/44: 103-140.

"Amin, S. (1989). El Eurocentrismo. Crítica de una ideología. Madrid: Siglo XXI.

"Artieda, T. (2001). La problemática aborigen en los libros de texto de la escuela elemental argentina (1946-1955), en: V Congreso Iberoamericano de Historia de la Educación Latinoamericana. San José de Costa Rica.

» Artieda, T., Rosso, L. y Ramírez, I. (2010). De "salvajes en extinción" a autores de textos. La producción de textos como expresión de conflictos interétnicos. 1880-1930/1987-2007, en: Artieda, T. (comp.), Los "otros" en los textos escolares. Conflictos en la construcción de imágenes de nación. Luján: Departamento de Publicaciones e Imprenta de la Universidad Nacional de Luján, 107-154. 
» Bergel, M. (2010). “Los bárbaros están otra vez sobre Roma”. Acerca de la reacción antioriental del pensamiento nacionalista católico argentino de los años 1920, en: Iberoamericana X/40: 7-26.

»Bergel, M. (2015). El Oriente desplazado. Los intelectuales y los orígenes del tercermundismo en la Argentina. Buenos Aires: Universidad Nacional de Quilmes.

" Bernal, M. (1993 [1987]). Atenea Negra. Las raíces afroasiáticas de la civilización clásica. Barcelona: Crítica.

»Bessis, S. (2003). Western Supremacy. The Triumph of an idea. Londres: Zed Books.

"Biagini, H. (1995). La Generación del Ochenta. Cultura y política. Buenos Aires: Editorial Losada.

"Briones, C. (1998). La alteridad del "Cuarto Mundo". Una deconstrucción antropológica de la diferencia. Buenos Aires: Ediciones del Sol.

" Castro Gómez, S. (2000). El mundo ya no es ancho pero sigue siendo ajeno. Fin de la modernidad y transformaciones de la "cultura" en tiempos de globalización, en: Lander, E. (ed.), La colonialidad del saber: eurocentrismo y ciencias sociales. Perspectivas Latinoamericanas. Buenos Aires: CLACSO, 145-162.

»Devoto, F. (1993). Idea de Nación, Inmigración y Cuestión Social en la historiografía académica y en los libros de texto de Argentina (1912-1974), en: Propuesta Educativa 8/5: 9-30.

»De Sena, I. (2008). Beduinos en la pampa. El espejo oriental de Sarmiento, en: Nagy-Zekmi, S. (ed.), Moros en la costa. Orientalismo en Latinoamérica. Madrid: Iberoamericana, 69-90.

»Díaz, M. (2012). Racismo y otredad en el positivismo argentino. Algunas notas sobre Carlos Bunge y José Ingenieros, en: Revista de Epistemología y Ciencias Humanas 4: 54-70.

"Díaz, M. (2017). Racismo epistemológico y occidentalocentrismo: apuntes para una descolonización de la tradición hegemónica del conocimiento, en: Revista de Epistemología y Ciencias Humanas 9: 1-18.

》Dobaño, P., Lewkowicz, M., Mussi, R. y Rodríguez, M. (2001). Los libros de texto como objeto de estudio: un balance de la producción académica 1983-2000, en: Dobaño, P. y Rodríguez, M. (comps.), Los libros de texto como objeto de estudio. Buenos Aires: La Colmena, 11-32.

»Dussel, E. (2000). Europa, modernidad y Eurocentrismo, en: Lander, E. (ed.), La colonialidad del saber: eurocentrismo y ciencias sociales. Perspectivas latinoamericanas. Buenos Aires: CLACSO, 41-44.

"Funes, P. y Ansaldi, W. (1994). Patologías y rechazos. El racismo como factor constitutivo de la legitimidad política del orden oligárquico y la cultura política latinoamericana, en: CUICUILCO. El tiempo y las palabras 1/2: 193-229.

»Gasquet, A. (2008). El Orientalismo argentino (1900-1940). De la revista Nosotros al Grupo Sur, en: Documento de trabajo № 22. College Park: University of Maryland. Disponible en www.lasc.umd.edu.

" Gasquet, A. (2015). El llamado de Oriente. Historia cultural del Orientalismo argentino (1900-1950). Buenos Aires: Eudeba.

» Gvirtz, S., Oelsne, V. y Coria, J. (2001). Los libros de texto en la construcción 
de la ciudadanía, en: Semana del Libro, La construcción de la ciudadanía en los textos escolares. Buenos Aires: Biblioteca del docente. Disponible en: http:// estatico.buenosaires.gov.ar/areas/educacion/bibleduc/pdf/libros_de_texto.pdf

» Hegel, G.W.F. (1997 [1822-1831]). Lecciones sobre la filosofía de la historia universal (I). Barcelona: Altaya.

"Kaufmann, C. (2002). Producciones sobre textos escolares argentinos: hitos, tendencias y potencialidades, en: Anuario de Historia de la Educación, Sociedad Argentina de la Educación 4: 37-59.

"Lander, E. (2000). Ciencias Sociales: saberes coloniales y eurocéntricos, en: Lander, E. (ed.), La colonialidad del saber: Eurocentrismo y ciencias sociales. Perspectivas latinoamericanas. Buenos Aires: CLACSO, 11-40.

»Liverani, M. (1999). Ancient Near Eastern History from Eurocentrism to an 'Open' World, en: Isimu: Revista sobre Oriente Próximo y Egipto en la antigüedad 2: 3-9.

»López Facal, R. (2010). Nacionalismos y europeísmos en los libros de texto: identificación e identidad nacional, en: Clío y Asociados 14: 9-33.

»Martinelli, M. (2010). Los conceptos de raza y nación en perspectiva histórica. Sus influencias en el surgimiento del nacionalismo israelí, en: Antíteses 3/6: 1077-1093.

» Nagy-Zekmi, S. (2008). Buscando el Este en el Oeste: practicas orientalistas en la literatura latinoamericana, en: Nagy-Zekmi, S. (ed.), Moros en la costa. Orientalismo en Latinoamérica. Madrid: Iberoamericana, 11-24.

»Ossenbach, G. (2000). La investigación sobre los manuales escolares en América Latina: La contribución del proyecto MANES, en: Anuario Historia de la Educación 19: 153-164.

»Pfoh, E. (2010). Una deconstrucción del pasado de Israel en el antiguo Oriente: Hacia una nueva historia de la antigua Palestina, en: Estudios de Asia y África 45/3: 669-697.

»Pfoh, E. (2013). Revisitando el mito del despotismo oriental: Por una antropología política crítica de Medio Oriente, en: ANMO: África del Norte y Medio Oriente 2-3/2: 108-127.

"Privitellio, L. (1999). Nosotros y los otros en los manuales de Historia Argentina, en: Il Seminario Bianual: Enseñanza de la Historia y Geografía en el contexto del Mercosur. Montevideo: 29-33.

"Quijano, A. (2000). Colonialidad del poder, eurocentrismo y América Latina, en: Lander, E. (ed.), La colonialidad del saber: eurocentrismo y ciencias sociales. Perspectivas latinoamericanas. Buenos Aires: CLACSO, 201-246.

»Riekenberg, M. (1991). Latinoamérica: Enseñanza de la historia, libros de textos y conciencia histórica. Buenos Aires: Alianza.

»Romero, L. A. (coord.). (2004). La Argentina en la escuela. La idea de nación en los textos escolares. Buenos Aires: Siglo XXI.

»Romero, L. A. (2009). Enfrentar al enano nacionalista: una mirada a los libros de texto, en: Temas de historia argentina y americana 14: 197-214.

"Romero L. A. (2010). Soberbia y paranoia. La idea de nación en los libros de texto del siglo XX, en: Devoto, F. (dir.), Historiadores, ensayistas y gran público. La historiografía argentina en los últimos veinte años (1990-2010). Buenos Aires: Biblos, 75-82. 
»Rosso, A. y Daneri, A. (1999). La inmigración judía y la cultura nacional. Abraham Rosenvasser y los estudios orientales en la Argentina, en: Trabajos y Comunicaciones 25: 43-69.

» Said, E. (2004 [1978]). Orientalismo. Barcelona: Debolsillo.

"Sand, S. (2011). La invención del pueblo judío. Madrid: Akal.

» Taboada, H. (1998). Un Orientalismo periférico: viajeros latinoamericanos, 1786-1920, en: Estudios de Asia y África 33/2: 285-305.

» Taboada, H. (2008). La sombra del Oriente en la Independencia Americana, en: Nagy-Zekmi, S. (ed.), Moros en la costa. Orientalismo en Latinoamérica. Madrid: Iberoamericana, 25-40.

»Teobaldo, M. y Nicoletti, M. A. (2007). Representaciones sobre la Patagonia y sus habitantes originarios en los textos escolares (1886-1940), en: Quinto Sol 11: 169-194.

»Teobaldo, M., García, A., Nicoletti, M. A. y Miralles, G. (2008). La Patagonia en los textos escolares: Un relato acerca de la investigación, en: Cuadernos de Educación 6/VI: 143-153.

»Todorov, T. (1991). Nosotros y los Otros. Reflexiones sobre la diversidad humana. Madrid: Siglo XXI.

»Ueno, C. (2001). Orientalismo y género, en: Debate Feminista 21/12: 165-175.

"Wallerstein, I. (2000). El eurocentrismo y sus avatares: Los dilemas de las ciencias sociales, en: New Left Review o: 97-113.

»Zingarelli, A. P. (1996). Algunas consideraciones sobre la propuesta editorial para enseñanza de Historia Antigua, en: Clío y Asociados 1: 81-89. 
